\title{
A Defence of Unqualified Pharmaceutical Confidentiality
}

\author{
Rahul Hajare* \\ Department of Health Research Government of India, Indian Council of Medical Research, India
}

Submission: October 27, 2017; Published: November 15, 2017

*Corresponding author: Rahul Hajare, As a Former Post Doc Fellow 2013 (7th Batch) Indian Council of Medical Research, Department of Health Research Govt. of India, India, Email: rahulhajare@rediffmail.com

\section{Mini Review}

Being a molar agent, particularly in our private pharmaceutical institution cum professional role has been accepted difficult and agonizing since there are no molar absolute determinations. The use of ethics combination has revolutionized the treatment of malpractices, but there is no equivalent combination has exists for prevention, particularly for transmission of unethical practises. Strategies to combine incompatible agents may facilitate the discovery of unique activities particularly unexplored combination of habits. A remote area of pharmaceutical institution bears the burden of the honesty, culture draws and developments of NAAC NBA are disproportionately affected by the pandemic.

Staff account for three quarters by parts of college pharmaceuticals between the age 25 to 35 who are smoker addict and tobacco chewing, split anywhere in college is the leading cause of unbioethics among staff of respective ages. In the absence of an effective ideology, unidirectional work, embarking, blaming, accusing and as long as new progressions of unseen continue to outpace advances made in the treatment with orientation therapy and guideline. Intension compromises, nobody care. It has an atmospheric condition in which certain members (including the normal staff in excess with nonteaching) have present in blaming which can cause undesirable effects on students and their environment.

This staffs has been approved as a qualified that are not mediated by the ability to isolate a distinct pathway by which a staffs may have anaphylactic potential, is identified. A Defense of unqualified pharmaceutical confidentiality," would have us think otherwise. He argues that principals should never breach confidentiality, no matter what kind or amount of grave harm to another college staff could be averted and even when the college staffs acknowledges that male staff or female staff intends to put another college staff at risk of grave harm without that college staff's knowledge and habit.

The value of confidentiality trumps all others for principals of the colleges. Confidentiality is absolute, so that even in the face of a college staff disclosing that he intends to harm another college staff the principal would do wrong to inform that threatened college staff of the impending grave harm. There is something comforting about the simplicity of this account of professional obligations; there is nothing for principals to deliberate or worry about when faced with such circumstances. The good human will not tell ever. Nevertheless, this account belies the complexity of our professional (and college staff) moral lives. All our obligations are open to countervailing obligations in particular circumstances; all things considered principals of the college should keep the confidences of their staff individual. Not any reason will be sufficient to disclose, in fact, possibly just one reason is sufficient to override that obligation to not tell- avoiding grave harm to another college staff. Being trustworthy means keeping promises, including promises not to disclose information, but again it does not entail that one will never disclose information or break promises.

Unfortunately, honesty, moral duties, virtues, role of teacher and values do not come to us with tidy lists of rules to follow. Morality is messier than that because it is more complicated than this view suggests. What motivates argument for unqualified medical confidentiality? To supports argument for the absolute obligation to retain the confidences of staffs with, ironically, a consequentialist argument that more endangered third parties will be protected by his account than the alternative account that requires reporting to endangered third parties. Let me detail the reasons why his arguments do not work. Rightly points out that problem arise in moral decision making when core values of a profession are in conflict with one another and liberty is more powerful and accepted only things it cannot have unless you are willing to give it to others. Moral conflicts are the mainstay of compelling fiction; who had to struggle with the fugitive slave laws having as they did values pulling them in opposite directions.

Characterizes the conflict in core values in infected staff's by parts case as trustworthiness to and beneficence. Two points 
about this characterization of the problem: First, there is a significant issue of trustworthiness toward staffs as well. They trust his director to inform his about conditions or events that will be harmful to health. Since new staff is his college staff too, he has significant direct duties to him).Infected staff is not some unknown college staff to our principal, but he is his college staff with expectations about what his principal will do when he has knowledge of grave health risks to him. Characterization of a conflict between trustworthiness and beneficence misses the trust that has placed in his doctor. Second, the characterization of the duty of beneficence to staff does not express the complexity of that value.

Beneficence includes multiple duties, some more or less stringent than others. It includes doing good for others, advancing their welfare but also includes not doing harm and preventing harms to others. The latter, not harming and preventing harmsnon maleficence-is more stringent than the former-doing good or advancing their welfare. Portrayal suggests that the duty to infected staff is merely to advance her/him welfare and thereby minimizes the stringency of the duty to staff. If there is a conflict between values, argues, we need a priority rule. Presentation implies that there is a priority rule for all conflicts of values. He states that when autonomy and beneficence, for instance, conflict, autonomy wins out. There are not, regrettably, priority rules for all conflicts of values. And even when there is a priority rule, as in the states where there is a very strong presumption in favor of autonomy, it is not absolute. We can imagine cases where all things considered the good human will override autonomy in favour of beneficence. Ironically, where there is compelling justification for a priority rule is in cases where principals can only prevent serious risk of harm to identifiable college staffs by divulging information about their staffs. First do no harm is a very convincing overriding rule. What is argument for the unqualified position on confidentiality? His argument is a form of rule utilitarianism, viz. adopting the unqualified confidentiality rule will have better consequences, protect more people, than the alternative.
The alternative rule is to tell staffs that you as a principal will keep their medical information and the details of their discussions confidential; however, the only circumstance that would compel you to disclose information are instances where the staffs behavior will lead to a high probability of serious risks of harm to others (and in the case of infectious diseases this would occur only if the college staff confides that he or she is going to engage in risky behavior with others without their knowledge).

Empirical data suggesting that reporting to third parties does not appear to decrease rates of testing is especially compelling. Needs the empirical support for his rule that absolute confidentiality results in protecting more endangered parties, but unfortunately he does not have that empirical support. In the current situation, college principal do disclose under circumstances of threats to unwitting third parties and yet people continue to be tested and confide in principals. Contention for this unqualified confidentiality would have been stronger with a principled argument, but alas I don't think that there is a good principled argument to advance in support of it [1-4].

\section{References}

1. Rahul Hajare (2017) Early Rising May Be Linked to Mental Health Issues in Institute of Pharmaceutical Science an Observational Study Draws Inference from a Legal to Cultural Principles through Independent Variables. Biomed J Sci \& Tech Res 1-2.

2. Rahul Hajare (2017) The Impact of Relocation and Transfer of naive B.Pharm Students to Adjacent Class room in Privately Managed Self finance Co-Educational Pharmaceutical Institute and Survey Investigation of Attitude towards Pharmaceutical Syllabus. Biomed J Sci \& Tech Res 1-2.

3. Rahul Hajare (2017) Process from Biosafety Working Style to Accreditation Trends Driving Self-financed Private Pharmacy Institution in Remote Areas Individuals in India. J Tradit Med Clin Natur 6(2-3).

4. Rahul H (2016) pre DR Technology, Kenkyu Journal of AIDS \& Clinical Trials. 2-3.

Your next submission with Juniper Publishers
will reach you the below assets
- Quality Editorial service
- Swift Peer Review
- Reprints availability
- E-prints Service
- Manuscript Podcast for convenient understanding
- Global attainment for your research
- Manuscript accessibility in different formats
( Pdf, E-pub, Full Text, Audio)
- Unceasing customer service
Track the below URL for one-step submission
https://juniperpublishers.com/online-submission.php

